\title{
Prevalence and risk factors for intestinal parasite infections in schoolchildren, in the city of Santarém, Pará State, Brazil
}

\author{
Prevalência e fatores de risco para infecções por parasita intestinal em \\ crianças de escolas na cidade de Santarém, estado do Pará, Brasil
}

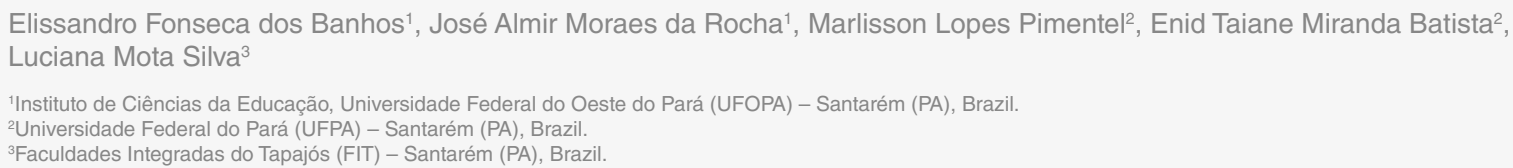

DOI: http://dx.doi.org/10.7322/abcshs.v42i3.932

\begin{abstract}
Introduction: Intestinal parasites are common in children in poor countries around the world, and are the cause of serious health problems. Objective: To evaluate the prevalence of intestinal parasites in schoolchildren in Santarém, and associated socio-environmental risk factors. Methods: Questionnaires were applied to parents, and fecal exams were performed by direct method and sedimentation. Results: The parasites that prevailed were Entamoeba coli (20.4\%) and Ascaris lumbricoides (9.0\%). The family income is an important factor related to parasitic infections $\left(\chi^{2}=21.000 / p=0.001\right)$. Other factors such as water treatment $\left(\chi^{2}=20.15 / p=0.002\right)$, health infrastructure $\left(\chi^{2}=25.40 / p=0.001\right)$, and hygiene practices such as hand washing $\left(\chi^{2}=11.54 / p=0.003\right)$ were statistically significant for the presence of intestinal parasites too, some on a lesser scale. Conclusion: The results showed that Entamoeba coli and Ascaris lumbricoides are the prevalent parasites. The family income, water quality, and sanitary infrastructure are the main risk factors for parasitic infections.
\end{abstract}

Keywords: helminths; protozoan infections; child; basic sanitation; parasitology.

\section{RESUMO}

Introdução: As parasitoses intestinais são comuns em crianças em países pobres pelo mundo, e são a causa de sérios problemas de saúde. Objetivo: Avaliar a prevalência de parasitos intestinais em crianças de escolas em Santarém, e fatores de risco socioambientais associados. Métodos: Foram aplicados questionários as famílias, e os exames de fezes foram realizados pelo método direto e sedimentação. Resultados: Os parasitas que prevaleceram foram Entamoeba coli (20,4\%) e Ascaris lumbricoides $(9,0 \%)$. A renda familiar é um fator importante relacionado às infecções parasitárias $\left(\chi^{2}=21.000 / p=0.001\right)$. Outros fatores como o tratamento da água $\left(\chi^{2}=20.15 / p=0.002\right)$, infraestrutura de saúde $\left(\chi^{2}=25.40 / p=0.001\right)$, e práticas de higiene como lavagem das mãos $\left(\chi^{2}=11.54 / p=0.003\right)$ foram também estatisticamente significativos para a presença de parasitas intestinais, alguns em menor escala. Conclusão: Os resultados mostraram que Entamoeba coli e Ascaris lumbricoides são os parasitos prevalentes. A renda familiar, qualidade da água, e infra-estrutura sanitária são os principais fatores de risco para infecções parasitárias.

Palavras-chave: Helmintos; infecções por protozoários; criança; saneamento básico; parasitologia. 


\section{INTRODUCTION}

Despite all the scientific and technological developments through which the world has gone in the last 50 years, a disease that takes us back to the early seventeenth century is still present as a serious public health problem. This fact would not be so alarming if this disease was not directly linked to extreme poverty and lack of basic hygiene habits ${ }^{1}$.

Infections caused by intestinal parasites are frequent in children in poor or developing countries, and are the cause of health problems, besides a significant number of deaths among children aged 1-6 years ${ }^{2,3}$.

The World Health Organization estimates that $60 \%$ of the world population is infected by parasites; 3.5 billion of them are children infected by intestinal parasites that can cause some health problems $\mathrm{s}^{3,4}$. Studies in Brazil have shown that frequency of helminths and protozoa pathogens in children is high, and that the problem needs to be confronted directly and seriously ${ }^{5-8}$.

Most infections caused by intestinal parasites go unnoticed for years, and this is one of the causes of neglect and lack of immediate treatment. The late diagnosed symptoms may cover a number of consequences for the development of these children, which over time can present malnutrition and anemia, leading to growth retardation and low academic achievement ${ }^{9-12}$.

In many cities in Pará State, Brazil, this problem can be more severely present, because most of the population do not have running water, and no sewage treatment, as all cities' sewage flows into the rivers and streams surrounding towns ${ }^{8}$. In addition, some families, due to the lack of information or unfavorable financial conditions, still use open-sky latrines that contaminate the soil and are responsible for entrainment of human excreta to groundwater used for the abstraction of water for consumption.

Because of the problem presented, this study aimed to examine the prevalence of intestinal parasites in primary school children in Santarém, in Pará State - Brazil, and the socio-environmental risk factors these children are subject to that may contribute to the appearance of these diseases.

\section{METHODS}

\section{Study area}

The city of Santarém is located in northern region of Brazil, precisely in state of Pará, in the Lower Amazon region, due to its geographical location: Situated at the confluence of the Tapajós and Amazon rivers, and at a distance of $800 \mathrm{~km}$ from Belém, the state capital ${ }^{13}$.

It occupies an area of $22.887 .080 \mathrm{~km}^{2}: 77 \mathrm{~km}^{2}$ in the urban area, with its population is estimated at 299.419 habitants. The dominant weather is hot and humid, typical of tropical forests, and the average annual temperature is $25-28^{\circ} \mathrm{C}$, with an average humidity of $86 \%{ }^{13,14}$.
Sanitation is constituted of a network of sewage with $50 \mathrm{~km}$ in length, and is inefficient, because there is no main collector, or treatment station. The Sanitation Company of Pará (COSANPA) supplies the water through 18 pools (groundwater abstraction), with a total of 30.200 active links, covering about $78 \%$ of the property ${ }^{13}$.

The Municipal Educational System is responsible for basic education and has 505 schools serving 65.361 students, including rural and urban areas. The Human Development Index (HDI) is 0.746 , above the Brazilian average, but still considered very low compared to other countries in the world ${ }^{13,15}$.

\section{Data collection}

The study was conducted from April to September 2007, May to October 2008, and April to September 2010, and was developed with primary school students in the urban area of Santarém. The first meetings were held with the principals of the selected schools, in order to present the project's objectives and to encourage participation of children and their families.

Meetings were also held with parents to recruit families with children aged between 4 and 12 years, who would be interested in participating in the project.

A questionnaire was used with each child to obtain information such as age, gender and exposures to health education. In addition, a questionnaire was applied to the parents for information about their occupation, family income, education level, number of family members, infrastructure of the house, hygiene, sanitation, access to water, basic hygiene habits, knowledge of the mode of intestinal parasitic infection and treatment.

\section{Collection analysis of fecal samples}

In selected schools, sample containers labeled with the name of the selected child and an identification number were distributed, and the collection procedure was explained. This explanation was sent to parents, as well as the sample storage procedure. The next morning, the containers were collected and transferred to Laboratory of Microbiology at University of Pará State (Santarém campus), where parasitological analysis tests were performed, two tests for sample. Children who had not provided a fecal sample were allowed one more day to provide the sample.

The direct method and sedimentation in water were used for identification of intestinal parasites. These methods were selected because they are relatively inexpensive and safe, and widely used in other studies ${ }^{16,17}$.

The infected children were treated with specific chemotherapy, and their medical report was given to the parents or guardians for immediate evaluation and control at local health service (health center), for monitoring and continuity of treatment.

\section{Data analysis}

Statistical analysis was done through the compilation of all data using Microsoft Excel 2010 (Microsoft Corporation), and 
analyzed in the 5.3 BioStat-version. Descriptive statistics were carried out. Frequencies were calculated for categorical variables (prevalence, etc.). The Chi-square $\left(\chi^{2}\right)$ was used to determine the relationship between the variables (socio-environmental risk factor) and the prevalence of parasitic infections in the studied population. $P$-values of $<0.05$ were regarded as significant.

\section{Ethical approval}

The research protocols used in the study followed the principles of the privacy of personal data laid down in the Declaration of Helsinki and amendments, and those provided for National Brazilian Legislation. The project was approved by Research Ethics Committee at University of Pará State Cod. 916.554.

\section{RESULTS}

A total of 367 families were selected, and only one child from each family participated in the study, which prevented repeatable results about the data collected in the questionnaire applied to the children's parents or guardians. This total of children was distributed to nine of the Municipal Primary Schools in Santarém. From this study group of 367 children, 178 were male, and 189 were female, both groups aged 4 to 12 years, divided between the age groups 4-6, 7-9 and 10-12 years.

Of the 367 fecal examinations performed, 189 (51.5\%) had some protozoan infection, and 59 (16\%) had a helminths infection, a prevalence of $67.5 \%$ in intestinal parasite sample analysis (Table 1). Entamoeba coli (20.4\%) were most common protozoan, followed by E. histolytica (13.9\%), and Giardia duodenalis (13.3\%). The most prevalent helminths were Ascaris lumbricoides (9.0\%), followed by Trichuris trichiura (2.1\%). Monoparasitism cases prevailed (51.6\%) compared to biparasitism cases $(4.6 \%)$ and polyparasitism infections (2.4\%) (Table 1 ).

Table 1: Prevalence of parasite species found in 367 elementary school children from the city of Santarém, Pará State

\begin{tabular}{|l|c|c|}
\hline Parasites & $\mathbf{N}^{\circ}$ & $\%$ \\
\hline Protozoa & 189 & 51.5 \\
\hline Entamoeba coli & 75 & 20.4 \\
\hline Entamoeba histolytica & 51 & 13.9 \\
\hline Giardia duodenalis & 49 & 13.3 \\
\hline Endolimax nana & 7 & 1.9 \\
\hline Enteromonas hominis & 7 & 1.9 \\
\hline Helminths & 59 & 16.0 \\
\hline Ascaris lumbricoides & 33 & 9.0 \\
\hline Trichuris trichiura & 8 & 2.1 \\
\hline Enterobius vermicularis & 6 & 1.6 \\
\hline Necator americanus & 6 & 1.6 \\
\hline Hymenolepis nana & 3 & 0.8 \\
\hline Strongyloides stercoralis & 2 & 0.5 \\
\hline Hymenolepis diminuta & 1 & 0.2 \\
\hline Monoparasitism & 189 & 51.6 \\
\hline biparasitism & 17 & 4.6 \\
\hline Poliparasitim & 9 & 2.4 \\
\hline Total & 248 & 67.5 \\
\hline
\end{tabular}

Among the infected children, males prevailed (65.1\%) over females (52.3\%), and statistical analysis indicated that gender is not a risk factor related to intestinal infections $\left(\chi^{2}=1.612 / p=0.204\right)$. Data obtained from questionnaires indicated that family income is an important factor related to parasitic infections $\left(\chi^{2}=21.000 / p=0.001\right)$.

Treatment of the water consumed also showed statistically significance for the presence of intestinal parasites $\left(\chi^{2}=20.15 /\right.$ $p=0.002)$, the health infrastructure and hygiene habits like washing hands also were significant in this type of infection with $\chi^{2}=25.40 / p=0.001$ and $\chi^{2}=11.54 / p=0.003$, respectively (Table 2 ).

The results also show that the age group with the largest number (\%) of infected children is between the ages of 4 to 6 years (78.9\%), followed by the 7 to 9 years $(59.3 \%)$ group, and lastly, the 10 to 12 years (35\%) group.

Table 2: Statistical analysis of the variables (risk factors) related to the prevalence of intestinal parasites

\begin{tabular}{|c|c|c|c|}
\hline Variable & $\begin{array}{l}\text { no. } \\
\text { examined }\end{array}$ & $\begin{array}{c}\text { no. } \\
\text { infected }\end{array}$ & $\begin{array}{c}\text { prevalence } \\
(\%)\end{array}$ \\
\hline \multicolumn{4}{|l|}{ Gender } \\
\hline Male & 178 & 116 & 65.1 \\
\hline Female & 189 & 99 & 52.3 \\
\hline Chi-square $\left(\chi^{2}\right)$ & & & 1.612 \\
\hline$p$-value & & & 0.204 \\
\hline \multicolumn{4}{|l|}{ Family income } \\
\hline$<$ Minimum wage & 136 & 111 & 81.6 \\
\hline One minimum wage & 135 & 79 & 58.5 \\
\hline Two minimum wages & 65 & 19 & 29.2 \\
\hline$\geq 03$ minimum wages & 31 & 6 & 19.3 \\
\hline Chi-square $\left(\chi^{2}\right)$ & & & 21.00 \\
\hline$p$-value & & & $0.001^{*}$ \\
\hline \multicolumn{4}{|l|}{ Water consumed } \\
\hline Untreated & 162 & 132 & 81.4 \\
\hline Hypochlorite & 112 & 37 & 33.0 \\
\hline Boiled & 51 & 31 & 60.7 \\
\hline Filtered & 42 & 15 & 35.7 \\
\hline Chi-square $\left(\chi^{2}\right)$ & & & 20.15 \\
\hline$p$-value & & & $0.002^{*}$ \\
\hline \multicolumn{4}{|l|}{ Waste disposal system } \\
\hline $\begin{array}{l}\text { Private backyard } \\
\text { (latrine) }\end{array}$ & 160 & 136 & 85.0 \\
\hline Bathroom with fossa & 176 & 58 & 32.9 \\
\hline Outside the house & 31 & 21 & 67.7 \\
\hline Chi-square $\left(\chi^{2}\right)$ & & & 25.40 \\
\hline$p$-value & & & $<0.001^{*}$ \\
\hline \multicolumn{4}{|l|}{ Treatment of the waste } \\
\hline Public collection & 191 & 108 & 56.5 \\
\hline Discarded in the yard & 127 & 83 & 65.3 \\
\hline Burnt & 49 & 24 & 48.9 \\
\hline Chi-square $\left(\chi^{2}\right)$ & & & 1.205 \\
\hline$p$-value & & & 0.547 \\
\hline \multicolumn{4}{|c|}{ Washing hands before meals } \\
\hline Always & 172 & 71 & 41.2 \\
\hline Never & 139 & 109 & 78.4 \\
\hline Sometimes & 56 & 35 & 62.5 \\
\hline Chi-square $\left(\chi^{2}\right)$ & & & 11.54 \\
\hline$p$-value & & & $0.003^{*}$ \\
\hline
\end{tabular}

*Statistically significant results. 


\section{DISCUSSION}

Little information is available on the prevalence of intestinal parasites in schoolchildren of the lower Amazon Region. We believe this is the first quantitative study treating scientific information that is relevant to decision-making on this aspect of public health in this region of Brazil. However, it is noteworthy that this study examined a percentage of approximately $0.5 \%$ of the school population of Santarém. Moreover, samples from town rural areas, where sanitation conditions are even more precarious, were not analyzed.

The results obtained in this study show a high prevalence of intestinal parasites (67.5\%) in primary school children of Santarém. The prevalence of protozoa and helminths in the investigated population resembles the results obtained in poor regions of Northeastern Brazil. Some results like the prevalence of A. lumbricoides, E. histolytica and G. duodenalis with $16.0 \%$, $13.9 \%$ and $13.3 \%$ respectively, outweigh the results founded in others works of the poorest regions of Brazil ${ }^{18}$.

The prevalence of parasites like E. coli, E. histolytica and G. duodenalis indicates the occurrence of food contamination by fecal material, because the transmission is generally linked to the consumption of unwashed vegetables. In this case, the establishment of healthcare policies aimed at the diagnosis and treatment of these specific sources of infection, both at school and in the homes of these children, is priority ${ }^{19}$.

When compared to studies conducted in other countries in Latin America, we can see a similarity in the incidence of both helminths, such as A. lumbricoides (16.0\%), and E. coli protozoa (20.4\%). Therefore, like in neighboring countries, the children of this region of Brazil are subject to abiotic and socio-environmental conditions contaminated by these pathogenic agents ${ }^{2,20}$.

A variety of intestinal parasites present in this population group indicates that the children of the city of Santarém are exposed to a large list of known disease-causing parasites, many of which are of epidemiological importance, as it is the case of A. Lumbricoides, E. vermicularis, T. trichiura, Necator americanus, E. histolytica and G. duodenalis. These parasites are the cause of serious human infections and even been reported as the cause of death among children, especially in poor and tropical regions ${ }^{3,20,21}$.

The prevalence of $A$. lumbricoides among helminths is probably related to the biology of this parasite, which has very resistant eggs with a great capacity to adhere to surfaces, an important factor for transmission, and its eggs are not easily removed by washing and may remain for up to ten years ${ }^{22}$.

In this work, we found the prevalence of monoparasite infections in $51.6 \%$ of the results, even though it is known that humans can host different parasite species, as well as the fact that the external environment provides high degrees of contamination and increase the probability of bi or polyparasitism infections, which should be happening in $4.6 \%$ and $2.4 \%$ of the observed results, respectively.
The prevalence of monoparasitism may be related to the low frequency with which the host comes into contact with the contaminated medium of the different species, to the immunocompetence of the host, or to the competition process that these parasites exert among themselves by the niche, leading to the exclusion of one of the species.

Concerning age group, it can be inferred that children aged between 4 and 6 years have a higher incidence because they are starting their school career, and therefore are still acquiring knowledge about proper hygiene habits that are important to prevent intestinal parasite infection.

The importance of family health education given to the children should not be ignored, but in many cases, this type of information has been the sole responsibility of the school.

Furthermore, it is expected that the immune system of children aged between 10-12 years is more efficient compared to that of younger children. This may also explain a lower incidence of intestinal parasites in this age group.

The results obtained through the application of questionnaires to the families proved important, as it deals with a public health problem that is related to a variety of environmental factors, and in order to seek solutions to the problem, it is necessary to understand, through a systematic analysis, which factors are the most statistically significant, showing their degree of relevance to the occurrence of parasite infection.

Among risk factors analyzed, the gender of the children was not statistically significant for the presence of intestinal parasites, and this in accordance with what was observed in other studies ${ }^{23,24}$.

An increased incidence in male children (65.1\%) compared to females (52.3\%), also observed in other studies, may be explained by the fact that boys in this age group are more exposed to contamination during peridomiciliary activities, since most children in this study have the backyards of their homes, streets and unpaved sports fields as places available to play in $\mathrm{in}^{7,23}$.

The results show that family income is an important variable for the presence of intestinal parasites, but it should be considered that this item is directly related to better hygiene conditions for the family, such as brick-built houses and proper toilets, for example. Similarly, water treatment is also a significant factor, since it is related to family income, and greater family income can provide an adequate treatment of the water consumed, such as the acquisition of filtration equipment, for example. Therefore, one needs to consider what a greater family income can provide for the environmental quality of life of these children.

The quality of the water consumed is a risk factor, and the results of this study corroborate this information already widely discussed in other studies ${ }^{25-27}$. The lack of water treatment benefits the maintenance of cysts and eggs by intestinal parasites that use water to be transported until they reach their new hosts.

The habit of washing hands can be considered the first barrier to fight intestinal parasite infections, as hand washing can interrupt the 
transmission of the parasite to the food, which, when ingested, drives the helminths eggs and protozoa cysts to the digestive organs of the host ${ }^{26}$. In our study, the habit of washing hands was also considered significant. Thus, it can be said that failure to carry out such hygiene habit is a risk factor for infection caused by intestinal parasites.

The analysis of health infrastructure of the households was one of the most alarming factors, mainly because most families use latrines, which consist of a small wooden houses in which they dig a hole in the ground for defecation. This behavior, often related to economic conditions, contaminate the soil and water sources nearby, thus spreading and the resuming the life cycle of most intestinal parasites.

In summary, the population studied is continuously exposed to infection caused by intestinal parasites; this is caused by the recurrent fecal contamination of soil and water, as discussed above, and, to some extend, by inadequate sanitation and hygiene. However, the study also shows that the living conditions of this population vary, so there are differences in the use of financial resources to prevent or try to prevent unfavorable hygienic conditions.
From this work, we can conclude that the prevalence of intestinal parasites in the school population of the city of Santarém is relatively large, considering the indexes of both protozoa and helminths found. The parasitic protozoan is prevalent, particularly amoebiasis and giardiasis. In this sense, a better monitoring, both on the side of the families and of schools, is needed on the environmental risks that these children are being exposed to. Low family income and lack of infrastructure of the houses showed preponderant among the risk factors related to the presence of intestinal parasites. Therefore, we can conclude that, if these contaminating problems were solved, they would significantly reduce the incidence of this disease.

\section{ACKNOWLEDGEMENTS}

We would like to thank the school principals, the children's parents, the coordination of Universidade Federal do Oeste do Pará (Santarém) and Celso Mattos Laboratory.

\section{REFERENCES}

1. Becker AA, loschpe R, Delwing D, Canali J. Incidência de parasitoses intestinais em escolares do município de Novo Hamburgo-RS. Rev Bras Anal Clín. 2002;34(2):85-7.

2. Rosado-García FM, Guerrero-Flórez M, Karanis G, Hinojosa MDC, Karanis P. Water-borne protozoa parasites: The Latin America perspective. Int J Hyg Environ Health. 2017;220(5):783-98. http://dx.doi.org/10.1016/j.ijheh.2017.03.008

3. Ximénez C, Morán P, Rojas L, Valadez A, Gómez A. Reassessment of the epidemiology of amebiasis: State of the art. Infect Genet Evol. 2009;9(6):1023-32

http://dx.doi.org/ 10.1016/j.meegid.2009.06.008

4. Alum A, Rubino JR, ljaz MK. The global war against intestinal parasites-should we use a holistic approach? Int J Infect Dis. 2010;14(9):e732-8.

https://dx.doi.org/10.1016/j.ijid.2009.11.036

5. World Health Organization. Prevention and control of intestinal parasitic infections. Report of a WHO expert committee. Geneva: WHO; 1987.

6. Quadros RM, Marques SMT, Arruda A, Delfes PSWR, Medeiros IAA. Parasitas intestinais em centros de educação infantil municipal de Lages, SC, Brasil. Rev Soc Bras Med Trop. 2004;37(5):422-3. http://dx.doi.org/10.1590/S0037-86822004000500012

7. Tashima NT, Simões MJS. Parasitas intestinais. Prevalência e correlação com a idade e com os sintomas apresentados de uma população infantil de Presidente Prudente-SP. Rev Bras Anal Clín. 2005;37(1):35-9.

8. Santo CKS, Grama DF, Limongi JE, Costa FC, Couto TR, Soares $\mathrm{RM}$, et al. Epidemiological, parasitological and molecular aspects of Giardia duodenalis infection in children attending public daycare centers in southeastern Brazil. Trans R Soc Trop Med Hyg. 2012;106(8):473-9.

http://dx.doi.org/10.1016/j.trstmh.2012.05.011
9. Muehlen M, Feldmeier $H$, Wilcke T, Winter B, Heukelback J. Identifying risk factors for tungiasis and heavy infestation in a resource-poor community in northeast Brazil. Trans R Soc Trop Med Hyg. 2006;100(4):371-80

http://dx.doi.org/10.1016/j.trstmh.2005.06.033

10. Rodrigues-Morales A, Bolivar-Mejía A, Alarcón-Olave C, CalvoBetancourt LS. Parasites in Food: Illness and Treatment. Encyclopedia Food Health. 2016;213-8.

11. Tarleton JL, Haque R, Mondal D, Shu J, Farr BM, Petri WA Jr. Cognitive effects of diarrhea, malnutrition, and Entamoeba histolytica infection on school age children in Dhaka, Bangladesh. Am J Trop Med Hyg. 2006;74(3):475-81.

12. Venkatachalam PS, Patwardhan VN. The role of Ascaris lumbricoides in the nutrition of the host: effect of ascariasis on digestion of protein. Trans $R$ Soc Trop Med Hyg. 1953:47(2): 169-75. http://dx.doi.org/10.1016/0035-9203(53)90074-1

13. Instituto Brasileiro de Geografia e Estatística. Censo demográfico de 2010 [Internet]. 2010 [cited on 2015 Sep 10]. Available from: http://www.ibge.gov.br/home/estatistica/populacao/censo2010/ default.shtm

14. Instituto Nacional de Pesquisas Espacial. Centro de previsão do tempo e estudos climáticos. [Internet]. [cited on 2015 Sep 10]. Available from: http://www.cptec.inpe.br/clima

15. Brasil. Programa das Nações Unidas para o Desenvolvimento (PNUD). Atlas [Internet]. [cited on 2015 Sep 10]. Available from: http://www.pnud.org.br/atlas/ranking/IDH_Municipios_Brasil_2000

16. Hoffman W, Pons JL, Janer JL. The sedimentation - concentration methods in Schistosoma mansoni. J Publ Health. 1934;9:283-91.

17. Amato VN, Campos R, Ferreira CS. Diagnóstico das parasitoses intestinais pelo exame de fezes. São Paulo: Atheneu; 1963. 
18. Alves JR, Macedo HW, Ramos Jr. NA, Ferreira LF, Gonçalves MLC, Araújo A. Parasitoses intestinais em região semi-árida do Nordeste do Brasil: resultados preliminares distintos das prevalências esperadas. Cad Saúde Pública. 2003;19(2):667-70. http://dx.doi.org/10.1590/S0102-311X2003000200034

19. Gioia I. Prevalência de parasitoses intestinais entre os usuários do centro de saúde do distrito de Sousas, Campinas, SP (19861990). Rev Soc Bras Med Trop. 1992;25(3):177-82. http://dx.doi.org/10.1590/S0037-86821992000300005

20. Bracciaforte R, Varengo H, Díaz MF, Pivetta VV, Burstein V, Orsilles MA. Enteroparásitos en niños y adolescentes de uma comuna periurbana de la província de Córdoba. Acta Bioquím Clín Latinoam. 2010;44(3):353-8.

21. Adedayo O, Nasiiro R. Intestinal parasitoses. J Nat Med Assoc. 2004;96(1):93-6

22. Luduvice M. Experiência da Companhia de Saneamento do Distrito Federal na reciclagem agrícola de biossólido. In: Bettiol W, Camargo AO (Eds.). Impacto ambiental do uso agrícola do lodo de esgoto. Jaguariúna: Embrapa Meio Ambiente; 2000. p.245-58.

23. Ugbomoiko US, Dalumo V, Ofoezie IE, Obiezue RNN. Socioenvironmental factors and ascariasis infection among school-aged children in Ilobu, Osun State, Nigeria. Trans R Soc Trop Med Hyg. 2009;103(3):223-8

https://dx.doi.org/10.1016/j.trstmh.2008.12.014

24. Pereira CW, Santos FN. Prevalência de geo-helmintíases em crianças atendidas na rede pública de saúde de Neópolis município do estado de Sergipe. Rev Bras Anal Clín. 2005;37(2):113-16

25. Gamboa MI, Navone GT, Orden AB, Torres MF, Castro LE, Oyhenart EE. Socio-environmental conditions, intestinal parasitic infections and nutritional status in children from a suburban neighborhood of La Plata, Argentina. Acta Trop. 2011;118(3):184-9. https://dx.doi.org/10.1016/j.actatropica.2009.06.015

26. Fonseca EOL, Teixeira MG, Barreto ML, Carmo EH, Costa MCN Prevalência e fatores associados às geo-helmintíases em crianças residentes em municípios com baixo IDH no Norte e Nordeste brasileiros. Cad Saúde Pública. 2010;26(1):143-52. http://dx.doi.org/10.1590/S0102-311X2010000100015

27. Silva JC, Furtado LFV, Ferro TC, Bezerra KC, Borges EPB, Melo ACFL. Parasitismo por Ascaris lumbricoides e seus aspectos epidemiológicos em crianças do Estado do Maranhão. Rev Soc Bras Med Trop. 2011:44(1):100-2.

http://dx.doi.org/10.1590/S0037-86822011000100022 